\title{
Measurement Invariance of the Sensitive Assessment for Gender Equality (SAGE) Index Across Degree: Findings from two Teacher Education Programmes in Spain
}

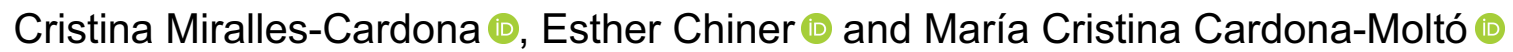 \\ University Institute for Gender Studies Research (IUIEG), Universidad de Alicante, Spain
}

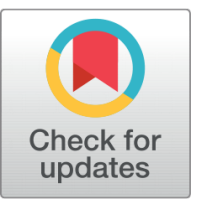

Received 2020-07-13
Revised 2020-07-15
Accepted 2020-07-22
Published 2021-01-15

Corresponding Author Cristina Miralles-Cardona, cmc138@alu.ua.es

Instituto Universitario de Investigación de Estudios de Género (IUIEG), Universidad de Alicante, Campus San Vicente del Raspeig, Aulario General II (Primera planta), Carretera San Vicente del Raspeig, s/n 03690 San Vicente del Raspeig, Alicante (Spain)

DOI https://doi.org/10.7821/ naer.2021.1.611

Pages: 157-174

Funding: Vice-Chancellor's Office for Educational Quality and Innovation (Education Sciences Institute) (Award: 4413) and by the Vice-Chancellor's Office for Research and Knowledge Transfer of the University of Alicante (Award; VIGROB-298)

Distributed under

Creative Commons CC BY 4.0

Copyright: ( ) The Author(s)

\section{ABSTRACT}

Western European countries have made impressive gender equality (GE) progress in education during the last few decades. Unfortunately, the implementation of gender mainstreaming (GM) in higher education has not been satisfactory. This paper describes a survey-based research study designed to explore student teachers' perceptions of training for GE in teacher education (TE) using the Sensitive Assessment for Gender Equality (SAGE) index. The study firstly aims to analyse the factor invariance across degree of the SAGE and secondly tries to describe the status of GM implementation in teacher education programmes from students' perspectives. Data were collected from 398 student teachers ( $84 \%$ female) aged 21.44 , enrolled on two TE programmes from a public higher education institution in the Autonomous Region of Valencia (Spain). Using single and multi-group CFA the study revealed that the proposed three-factor structure of the SAGE fitted well to early childhood and elementary school student teachers' data, thus suggesting equivalence between its components in both samples. Early childhood students scored significantly higher than elementary school student teachers in their reported perceptions of gender equality training and awareness of gender inequalities. Results will be displayed in terms of identifying institutional and curricular needs for GE education practices as findings reveal a clear demand for change.

\section{Keywords GENDER EQUALITY, PRESERVICE TEACHER EDUCATION, MEASUREMENT INVARIANCE, HICHER EDUCATION, SPAIN}

\section{INTRODUCTION}

Research in social sciences, particularly psychology and education, often compares groups of individuals with regard to different social, psychological and pedagogical variables. When these comparisons are made, it is assumed that the measuring instrument assesses the same constructs in all groups. If this assumption is true, the resulting comparisons will

\section{OPEN ACCESS}


be valid; however, if it turns out to be untrue, these comparisons lose validity and measurement equivalence may be questioned (Milfont \& Fischer, 2010). Measurement invariance is a statistical property that demonstrates whether measurements function in the same way across pre-specified groups (Vandenberg \& Lance, 2000). Testing for measurement equivalence has become an important issue in recent years (Cheung \& Rensvold, 1999) - especially within cross-cultural research because it allows researchers to verify if members of different groups ascribe the same meaning to the measurements made. Four levels of equivalence have been found in cross-cultural research (Fontaine, 2005): (1) functional equivalence, answers the question "Does the construct exist in every studied group?; (2) structural equivalence (Are items related to the construct?); (3) metric equivalence (Are loading weights identical across groups?); and (4) scalar equivalence (Are intercepts identical across groups?). This technique based on the structural equation modelling (SEM) framework can answer these questions through its ability to explore the equivalence of a given measure in multi-group data.

In the present study, a confirmatory factor analysis (CFA) serves to investigate measurement invariance in the Sensitive Assessment for Gender Equality (SAGE) index across degree. This instrument was designed to measure perceptions about the implementation of a gender perspective in teacher training. It consists of 18 items grouped into three subscales of five, seven and six items, respectively, which use a six-point Likert scale to measure the degree of agreement regarding: (a) institutional sensitivity to the application of gender equality policies; (b) the inclusion of gender issues into syllabuses/study plans; and (c) awareness of gender inequities associated with gender in teaching and learning. The purpose is to investigate whether measurement invariance in the SAGE index is supported across early childhood and elementary school student teachers at the construct definition level, the factor loading level, the intercept level, and the residual level. This analysis will have implications for SAGE index's validity. Supporting measurement invariance across degree would indicate both that the same construct is being measured and that mean comparisons are feasible.

\subsection{Initial Teacher Education for Gender Equality}

The expression "gender equality" appears in international declarations (CEDAW [UN, 1979]; Beijing Platform for Action [UN, 1995]; Millennium Development Goals [WHO, 2000]; Goald\#5 of the 2030 Agenda [UN, 2015]), in the European Union regulations for GE (e.g. European Pact for Gender Equality 2011-2020 [Council of Europe, 2011]) and in Spain's national policies (Organic Laws 1/ 2004 and 3/ 2007) claiming equal opportunities for men and women in all spheres of public and private life. Gender equality can be understood in multiple ways according to the evolution of this concept from a perspective oriented to fight against discrimination based on sex - rooted in the Women in Development (WID) approach - to one focused on changing oppressive structures through a Gender education and Development (G\&D) approach, which tends to emphasise the promotion of individual rights through a universal and institutional commitment. The emergence of gender equality during the 1960 s as a principle to achieve gender equity 
and combat discrimination between women and men has generated a series of debates, amongst which stands out the one revolving around gender mainstreaming —understood in higher education as the incorporation of a gender perspective into teaching, research and the governing bodies of universities.

European countries have made impressive progress toward gender equality in education during the last few decades. The EU's decision to adopt gender mainstreaming as a strategy to promote gender equality in all policies and programmes was established as a policy norm both in the Treaty of Nice (European Parliament, 2003) and in the Treaty of Lisbon (European Parliament, 2009). Since then, gender mainstreaming has become a longstanding priority for the European Commission. In March 2010, the Commission presented a "Women's Charter" expressing its increased commitment to gender equality that has been extended to the first Commission's Gender Equality Strategy 2014-2017 and to the second Gender Equality Strategy 2018-20203 (Council of Europe, 2018), both of which emphasise GM as a priority area of concern. In the follow-up process to the roadmap for gender equality the Commission stressed the need to develop and utilise specific methodologically gendered tools to foster the actual implementation of gender mainstreaming. However, in practice, a variety of contextual factors together with the lack of measurement instruments capable of evaluating the process itself and not only of accessing indicators has made it difficult to show evidence of progress on gender mainstreaming implementation (DeJaeghere, 2015).

Spain's efforts to promote education for gender equality began in the 1980s when its Government formally established a number of legislation policies as a signatory of the $1979 \mathrm{UN}$ Convention (UN, 1979), the Millennium Development Goals (WHO, 2000), and the 2030 Agenda (UN, 2015). Significant institutional changes were expected after the publication of Spanish Organic Law 3/ 2007 on "Effective Equality between Women and Men" (Spanish Government, 2007), which urges universities to train future professionals so that they can become competent in gender issues by mainstreaming gender into course contents and programmes (Art. 24).

\subsection{Gender equality training in higher education}

The UN Women Training Centre's 2015 Annual Report (UN Women Training Centre, 2015) labelled training as a powerful strategy to move individually and collectively towards gender equality by consciousness raising, learning empowerment, knowledge building, and skills development. Unfortunately, despite the mandatory nature of gender training, gender issues do not form part of university education yet (Lombardo \& Mergaert, 2013; Weiner, 2000). An ongoing debate exists about what components are needed for a successful approach to address gender equality in higher education. Preparing future professionals to adopt a gender approach in teaching involves not only identifying effective strategies but also taking into account instructors' skills and attitudes, as well as the specific situation of the country in question. This is undoubtedly a complex and challenging endeavour. Even when a course or a gender equality study unit incorporates features believed to be effective, students may end up graduating with conflicting views. This probably happens because 
students were not adequately supported in developing their own ethical commitment to gender equality or simply because their perception about their role in educating for gender equality conflicts with the views embedded in the curriculum. Hence, a literature review on gender mainstreaming implementation in university teaching practices in Spain was conducted. This review could provide insights into gender mainstreaming and gender equality training trends within Spanish higher education that would largely help inform institutions' decision-making with respect to the inclusion of a gender perspective in university curricula.

Globally, important collective bodies have documented the challenges faced by gender equality training and expressed their commitment to advancing knowledge on this topic. Several documents highlight the need to develop gender competence. The Convention on the Elimination of All Forms of Discrimination against Women (CEDAW) (United Nations, 1979) insists on the convenience of increasing knowledge on discrimination against women. The Beijing Platform for Action addresses the topic of gender equality competence development in nine of its 12 areas of concern, this being an important component of the strategic objectives of Area $\mathrm{H}$ on institutional mechanisms for the advancement of women. This critical area aims to guarantee the capacity for effective policy development aimed at achieving gender equality and is linked to the gender mainstreaming strategy. More specifically, strategic objective $\mathrm{H} 1$ advises governments to provide staff training for gender equality competence development, while objective $\mathrm{H} 2$ calls to provide training with the aim of integrating a gender perspective into all policies and programmes (UN Women Training Centre, 2015).

At an EU level, the Council of Europe reaffirmed its Member States' obligation to mainstream gender equality in every policy area at all stages and emphasised the need to develop and promote the use of GM tools and methods for gender equality training tailored to the specific needs of professionals and staff on 10 December 2013 (Council of Europe, 2011). However, the project Educating Teachers for Gender Equality (EIGE, 2012-2013) provides evidence that a significant percentage of teachers and instructors across countries have not been educated for mainstreaming gender equality in the educational processes.

Nationally, countries are facing different dilemmas and challenges when it comes to gender equality training. The distinct political, social and educational features of their national contexts, the outcomes of previous educational policies, and the expectations created by the new policies on gender equality determine each country's efforts and achievements. In Spain, as mentioned above, Art. 25.2 of Organic Law 3/2007 clearly states that higher education institutions will promote the inclusion of gender studies and training for gender equality in the curricula. However, in practice, the gender perspective has still not become a part of the university curriculum (Pastor \& Acosta, 2016). Having outlined the framework on initial education for gender equality, it is now important to describe the status of GM implementation in the different disciplines and studies, particularly as far as the Spanish higher education system is concerned. 


\subsection{Assessing gender mainstreaming implementation in university teaching}

Mainstreaming the gender perspective into university teaching involves the incorporation of gender issues into the educational processes, which affects not only study plans but also faculty and educators' ideology. This endeavour implies a process of reflection about the design of study programmes and course contents, as well as the use of a gender pedagogy meant to help students develop a gender sensitivity. This kind of competence is not learned automatically; it actually requires a systematic teaching process through which consciousness moves from stereotyped to committed gender conceptualization modes (Rands, 2009). Taking into account that university students finish their training period without an adequate GE competence preparation (Pendergast, Garvis, \& Keogh, 2011), gender education becomes increasingly demanding and necessary at all levels, since it evaluates the status of GM implementation. According to EIGE (2016), effective gender equality training (GET) requires not only a specific gender competence development but also institutional commitment and organisational strategies to design a well-defined framework within which gender competence development can be embedded in study plans.

EIGE's report on GET in the European Union (EIGE, 2014) concludes that, despite some important policy developments, most Member States still consider GET a low priority action. In the best of cases, training programs are often abstract and not tailored to participants' needs. Therefore, the quality of training programmes remains an issue, as no established mechanisms exist to ensure quality through setting standards on the verification of study plans and staff accreditation schemes (EIGE, 2012-2013). As a direct result of not having formally or informally imposed any quality standards, the efforts made to develop gender equality skills not always achieve the desired results.

The examination of the level of gender mainstreaming in university teaching undertaken by Spanish higher education institutions clearly shows that the topic is almost completely ignored in all university teaching fields and disciplines. Instead, continued reluctance exists to integrating gender into the higher education curriculum. Evidence thereof can be found in studies carried out within different fields/areas of knowledge such as education sciences (González-Pérez, 2017; Valdivieso, Ayuste, Rodríguez-Menéndez, \& VilaMerino, 2016; Vizcarra, Nuño, Lasarte, Aristizabal, \& Uria, 2015), communication (GarcíaRamos, Zurian-Hernández, \& Núñez-Gómez, 2020; Guarinos, Caro, \& Cobo-Durán, 2018), journalism (Larrondo \& Rivero, 2019), physical activity and sport sciences (Serra et al., 2018), political science (Verge, Ferrer-Fons, \& González, 2018) or didactics of social sciences (Ortega-Sánchez \& Pagès-Blanch, 2018).

In the field of teacher education, González-Pérez (2017) examined training for gender equality through an analysis of the main laws affecting the incorporation of a gender perspective into initial teacher training. She concluded that Spanish universities have done little to introduce education for gender equality, the result being that future teachers end their preparation with no opportunities to learn to teach in a gender-sensitive way. Valdivieso et al. (2016), in turn, carried out a critical analysis about the inclusion of a gender perspective in teacher education, which led her to the conclusion that such training hardly exists in 
Spain and that an adequate incorporation of the gender perspective in university teaching requires educators' preparation and involvement. After exploring the presence of gender content in the curricula of degrees in early childhood, elementary and secondary education of 44 Spanish universities, they found that only 11 of these higher education centres offered courses related to gender in their study plans and that they were generally elective subjects. Another five universities turned out to have subjects which, despite not including the word 'gender' in their titles, actually dealt with this topic in the syllabus. Ortega-Sánchez and Pagès-Blanch (2018) also studied the inclusion of a gender perspective in the curricula of elementary teacher education specifically analysing the teaching guides of subjects belonging to the area of Didactics of Social Sciences in the universities located in the Autonomous Region of Castilla and León. The results showed the maintenance of an asymmetric curriculum, not committed to education in and for gender equality, and aimed at strengthening gender-power androcentric dominance relationships. Other studies such as the one conducted by Vizcarra et al. (2015) across universities in the Basque Country reached similar conclusions supporting the invisibility of gender in elementary teacher education programmes.

García-Ramos et al. (2020) studied the presence of gender nationwide in the study plans of the degrees in communication offered by 55 Spanish public and private universities and 165 degrees and found that gender was absent in most study plans and, when present, it was addressed through optional subjects. Guarinos et al. (2018), who examined gender mainstreaming in the communication degrees of Andalusian public universities through a content analysis of 360 programmes, observed that only $9.5 \%$ of the analysed syllabuses made some reference to gender issues. Furthermore, many of them addressed it due to the specific nature of subjects (e.g. gender studies, sociology, psychology, ethics...). As for journalism, albeit more present than in communication, gender is still underrepresented. According to Larrondo and Rivero (2019), only one in every four of journalism curricula contain either an elective course on gender or a specific unit in gender.

Serra et al. (2018) also provide data about physical activity and sports which confirms the scarce presence of gender in the study plans in this curricular area. These authors examined 16 study plans from 37 Spanish universities and 763 documents, including textbooks. Their findings revealed five gender knowledge (in)visibility categories within universities' instructional discourse, gender knowledge being largely ignored in curricula and appearing, at best, in highly superficial ways. According to DeJaeghere (2015), this resistance to the incorporation of gender into education comes as no surprise considering the excessively technical and non-negotiated way in which GM has been defined as well as the universal character of the declarations of principles contained in international standards, which do not make it easy to locate and adapt such principles nationally, regionally or locally.

The same as in regard to gender mainstreaming scholarship and practice, more has been written on gender development measures being usually multidimensional indicators (e.g. measures of access to education) rather than focused on educational processes. As we move towards the 2030 Agenda (UN, 2015), a shift in emphasis is taking place that stresses the importance of learning objectives. In this context, a few examples of gender measures have 
emerged seeking to capture the multidimensional nature of gender equality through education. For example, Unterhalter, Heslop, and Mamedu (2013) developed three measures related to GE and schooling in Tanzania and Nigeria given a gender profile score, a gender management score, and a teacher qualification score. Less attention has been paid to developing measures for the assessment of GET levels in higher education, partly due to the positivistic and universal assumptions that characterise TE training. In this regard, Kabeer (2005, p. 23) argues that...

Gender inequalities are multidimensional and cannot be reduced to some single and universally agreed set of priorities. Any attempt to do so will run the danger of being either too narrow (as the MDGs have been accused of being) or a wish list that is too long and complex to act on. However, gender relationships are not internally cohesive ... A shift in one aspect of social relations can initiate a series of changes in other aspects, with unpredictable consequences.

The difficulty involved both in gender mainstreaming implementation and in its measurement justifies why it has not been easy to locate reliable and valid instruments to measure the status of gender mainstreaming incorporation into university teaching - with the exception of the SAGE training index (Miralles-Cardona, Cardona-Moltó, \& Chiner, 2020), specifically designed for its use in teacher education. Additionally, because testing measurement invariance becomes an essential requirement when trying to utilise an instrument to make comparisons between groups of different nature or characteristics (e.g. groups from different TE programmes), this study was developed with a twofold objective. Firstly, to investigate measurement invariance in the SAGE index across degree. And, secondly, to describe the status of GM implementation in two teacher education programmes by asking the following research questions: (1) How important do student teachers perceive gender equality training to be?; (2) Do they perceive their institution as being gender-sensitive and committed to a gender perspective approach?; and (3) To what extent are student teachers aware of gender inequalities in teaching and learning?

\section{METHOD}

\subsection{Context}

The study was a descriptive cross-sectional study carried out at the school of education of a public university located in the Spanish Region of Valencia. It concerned two teacher education programmes (early childhood and elementary education) at this institution, which offers accredited teacher education programmes designed to prepare teacher candidates for the K-12 setting. The total annual enrolment numbers at this School of Education amount to over 3,000 students/undergraduates (27\% males and $73 \%$ females) $-98 \%$ of them Spaniards - majoring in Early Childhood and Elementary Education (University of Alicante, 2018). Teacher education at this school is committed to providing teacher candidates with appropriate and sufficient training for them to understand, accept, and embrace equal gender opportunities as stated in the study programmes' foundations. Gender com- 
petence arises as a generic transversal competency, and with the exception of an elective course on "Teaching in Gender Equality", no study programmes show any evidence of gender issues having been incorporated into their course contents.

\subsection{Participants}

The study sample, formed by last-year undergraduate student teachers enrolled in two teacher education programmes (early childhood and elementary school education), was identified using the data available from the Institution's Office of Statistics for 2018. All 504 last-year student teachers from the aforementioned degrees were invited to participate. Three hundred and ninety-eight $(N=398)$ students ( $51 \%$ from early childhood and $49 \%$ from elementary school) completed the questionnaire with the SAGE index, which gives a response rate of $79 \%$. The sample consisted primarily of females (84\%). The mean age of participants was $21.44(S D=4.10)$-ranging from 18 to 50 years of age- and most of them were Spanish nationals (96.7\%). They had a full-time dedication to the degree programme (94\%). One third of respondents (37\%) claimed to have previous notions of gender equality issues. On the whole, respondents rated the importance of gender training with a score of 9.43 (out of 10).

\subsection{Instrument}

The Sensitive Assessment for Gender Equality (SAGE) index (student teacher's version) was used in this study. The theoretical support for this scale came from Doing Gender (West \& Zimmerman, 1987), a theory which conceptualises gender as a social and relational system interacting at three levels: socio-cultural (politics and laws); relational (curriculum and teaching); and individual (personal gender awareness). The items in this instrument were written after a literature review of relevant works published in the field of education for GE (e.g. UNESCO, 2015; UN Women, 2015). The initial SAGE version included 38 questions to participants about their degree of agreement on the level of GM implementation in their training programmes by means of a six-point Likert-type scale ranging from I Strongly Agree to I Strongly Disagree. The scale had been previously piloted (Miralles-Cardona, 2019), and after the preliminary analyses, 18 questions comprised the revised scale which showed evidence that the SAGE index was psychometrically sound in terms of item characteristics, scale reliability, and content validity.

\subsection{Procedure}

Data Collection. Based on an examination of university catalogues, one of the programme courses where all cohorts could be surveyed was selected. After being granted permission by the institution and the corresponding classroom instructors, participants were asked to give their informed consent. They anonymously and voluntarily completed the survey at the beginning of one of their classes during the second semester of the 2017-2018 academic year. From a total of 403 surveys, five turned out to be unusable for being incomplete. 
Data analysis. Data analysis entailed several phases. Firstly, SPSS version 26.0 was used for descriptive analyses, reliability (Cronbach's alpha coefficient) tests, and comparison of means ( $t$-test for independent samples and Cohen's $d$ to measure effect size). Secondly, single and multi-group CFA using AMOS version 23 (Arbuckle, 2014) allowed us to check the SAGE construct's validity. The normal distribution of data led us to opt for the Maximum Likelihood procedure. The following indeces were calculated for the purpose of assessing model fit: (1) the Chi-square statistic $\left(\chi^{2}\right)$, and the mean-square error of approximation (RMSEA) as absolute measures of fit; (2) the Tucker-Lewis index (TLI), and the comparative goodness index (CFI) as incremental adjustment measures; and (3) the $\chi 2 / d f$ ratio as a measure of parsimony adjustment. Adequacy of the hypothesised model was checked through the following cut-off criteria: for the $\chi 2 / d f$ ratio, a value of $\leq 2$ illustrates a good fit, a value of $\leq 3$ establishing an acceptable fit. For RMSEA, values of less than 0.05 reflect a close fit, while those above 0.08 suggest reasonable approximation errors (Browne \& Cudeck, 1992). CFI and TLI are considered appropriate with values $\geq$ than 0.90 . Nevertheless, Hu and Bentler (1999) appeal for more rigorous cut-off criteria when it comes to goodness of fit indeces, such as 0.95 for CFI and TLI or 0.06 for RMSEA. A factor invariance analysis was subsequently carried out for the two subsamples based on the best measurement model obtained at the previous stage.

\section{RESULTS}

\subsection{Normality check and reliability}

Table 1 shows the descriptive statistics (means, standard deviations, skewness, and kurtosis) for each one of the 18 SAGE index items. The highest average corresponds to item 20 "Gender issues are as important for TE as those related to other differences" - with a mean of 5.38 - and the lowest to Item 4 "Male students receive more attention from faculty than female students" - with a mean of 1.87 . Item 20 presents the most homogeneous responses ( $S D$ of 0.85 ), the most heterogeneous ones being those for Item 2 "My study plan includes gender competence development" (SD of 1.53). As shown in Table 1, almost all items met the normal distribution requirements for skewness and kurtosis values, which were within an acceptable range (between -2 and +2 ) as recommended by Muthén and Kaplan (1985) except for items 7, 13, 17, 19, and 20. Cronbach's Alpha of the overall SAGE index was .703 (.684 and .692 for early childhood and elementary school student teachers, respectively), values that fall within the high range of internal consistencies according to Thorndike (1997) and thus suggesting good reliability across subgroups.

\subsection{Measurement invariance across degree}

Guided by previous research on SAGE's dimensionality using student teacher samples (Kitta \& Cardona-Moltó, 2020; Miralles-Cardona, 2020; Miralles-Cardona et al., 2020) a threefactor model containing seven, five, and six items, respectively, was tested for both subsamples (early childhood and elementary school student teachers) prior to testing the SAGE factor invariance. Before comparing groups, it is important to make sure that the hypothet- 


\begin{tabular}{|c|c|c|c|c|}
\hline \multirow[t]{2}{*}{ Items } & \multicolumn{4}{|c|}{ Whole sample } \\
\hline & $M$ & $S D$ & Skewness & Kurtosis \\
\hline 2 & 3.88 & 1.53 & -0.313 & -0.936 \\
\hline 3 & 3.45 & 1.32 & -0.060 & -0.804 \\
\hline 4 & 1.87 & 1.19 & 1.581 & 2.095 \\
\hline 5 & 2.31 & 1.30 & 0.731 & -0.308 \\
\hline 6 & 2.91 & 1.45 & 0.295 & -0.908 \\
\hline 7 & 5.30 & 1.02 & -1.836 & 3.772 \\
\hline 8 & 2.80 & 1.44 & 0.285 & -0.926 \\
\hline 9 & 2.71 & 1.38 & 0.461 & -0.637 \\
\hline 10 & 2.05 & 1.08 & 0.909 & 0.248 \\
\hline 11 & 4.93 & 1.08 & -1.251 & 1.811 \\
\hline 12 & 4.84 & 1.27 & -1.123 & 0.803 \\
\hline 13 & 5.26 & 1.18 & -1.883 & 3.228 \\
\hline 14 & 3.72 & 1.20 & -0.345 & -0.305 \\
\hline 15 & 3.92 & 1.14 & -0.500 & 0.206 \\
\hline 16 & 4.21 & 1.13 & -0.566 & 0.372 \\
\hline 17 & 5.34 & 0.99 & -1.891 & 4.011 \\
\hline 19 & 5.22 & 0.95 & -1.449 & 2.499 \\
\hline 20 & 5.38 & 0.85 & -1.620 & 3.188 \\
\hline
\end{tabular}

ical structure provides good fit for both groups. For this purpose, we tested two three-factor models (M1 with 16 items and M2 with 18 items). After checking parameter estimates, a decision was made to take Model 2 - composed of 18 items - for checking invariance. The proposed three-factor model of the 18-item SAGE index (M2) fits the empirical data better than the 16-item three-factor model (M1) $\left(\chi^{2} / d f=3.50\right.$; RMSEA $<.08$; CFI $>.90 v s . \chi^{2} / d f$ $=6.13$; RMSEA < .11; CFI <.90).

Single CFA analysis. CFAs were run on each group to ensure satisfactory goodness of fit estimates. As shown in Table 2, RMSEA indicated an acceptable fit (.073 and .078) of the three-factor model in student teachers' data, as well as of the CFI (.901 to .945) and TLI (.900 to .944) indices. The fit for elementary school student teachers' data was less acceptable than for those corresponding to early childhood student teachers as can be easily observed (better $\chi^{2} / d f$, RMSEA and CFI indices in early childhood than in elementary school student teachers' samples). Factor loadings ranged from .59 to .82 , with a similar factor correlation in each subgroup, which varied between .02 and .35 in early childhood and between .13 to .35 in the elementary school student teachers' sample. Overall, this analysis provided evidence that the three-factor model and the 18 items of the SAGE is supported in both groups.

Multi-group CFA analysis. Next, the models were compared to find the optimal level of constraint. We moved from single-group CFA to multi-group CFA in order to cross-validate the three-factor model across the two groups. The configural, metric, and scalar models were hypothesised to be correct. Each model's fit was then compared against the fit of the 
Table 2 Goodness-of-fit indeces of 18-item SAGE measurement invariance across degree

\begin{tabular}{|c|c|c|c|c|c|c|c|c|}
\hline Model & $\chi^{2}$ & df & $\chi 2 / \mathrm{df}$ & $\Delta \mathrm{CFI}$ & TLI & $\triangle$ RMSEA & $\Delta \mathrm{CFI}$ & $\triangle$ RMSEA \\
\hline \multicolumn{9}{|l|}{ Single-group } \\
\hline Early Childhood & 296.20 & 147 & 2.01 & .945 & .944 & .073 & & \\
\hline Elementary & 390.50 & 147 & 2.66 & .901 & .900 & .078 & & \\
\hline \multicolumn{9}{|l|}{ Multi-group } \\
\hline Configural & 687.70 & 294 & 2.33 & .923 & .922 & .054 & & \\
\hline Weak & 695.30 & 300 & 2.32 & .923 & .922 & .054 & .000 & .000 \\
\hline Strong & 760.02 & 318 & 2.39 & .916 & .916 & .055 & .006 & .001 \\
\hline
\end{tabular}

Notes. $\chi 2=$ Chi-Squared; $\mathrm{df}=$ Degree of Freedom; CFI $=$ Comparative Fit Index; TLI $=$ Tucker-Lewis Index; RMSEA = Root Mean Squared Error of Approximation

model in which it was nested. Configural invariance tested whether the proposed factor structure (Figure 1) would be equal across both groups of student teachers. Fit indices $\left(\chi^{2} / d f\right.$ $=2.33 ;$ RMSEA $<.05 ;$ CFI $>.90$ ) confirmed this (see Table 2 ). The model fit of the other two invariances was similarly confirmed too: metric $\left(\chi^{2} / d f=2.32\right.$; RMSEA $\left.<.05 ; \mathrm{CFI}>.90\right)$ and scalar $\left(\chi^{2} / d f=2.39\right.$; RMSEA < .05; CFI $\left.>.90\right)$. As shown in Table 2 , the $\triangle \chi 2$ values at each comparison level allow accepting metric invariance, which leads us to conclude not only that factor loadings are equivalent in both samples but also that the models are equivalent with respect to factor loadings and intercepts. Adding more constraints to the configural model and later to the metric model and converting it to the scalar model did not result in the deterioration of fit (incremental indices of .001 for $\triangle D R M S E A$ and .006 for $\triangle \mathrm{CFI}$ ). These two models are equivalent at a configural, metric, and scalar level.

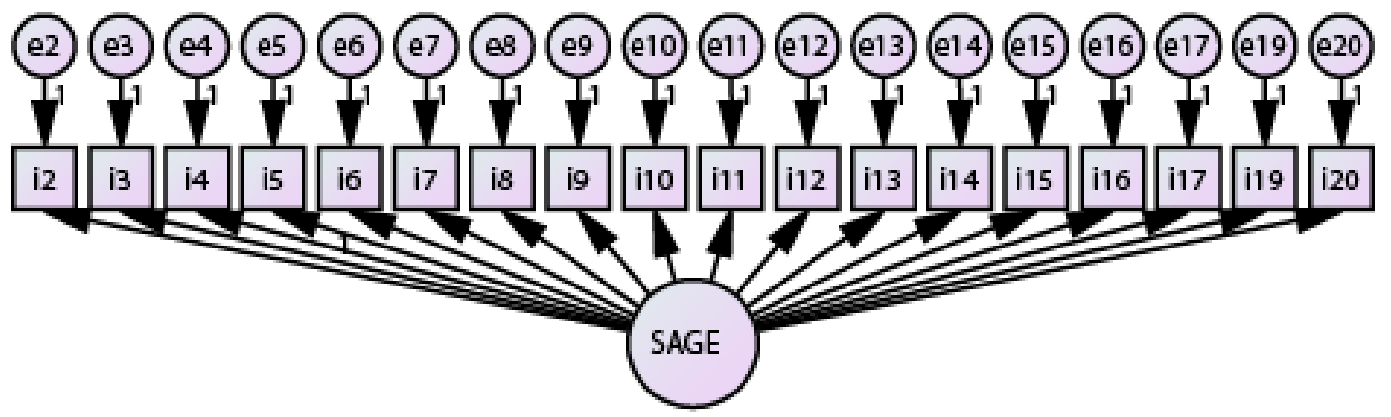

Figure 1 CFA model for assessing measurement invariance

\subsection{Perceptions about gender mainstreaming implementation and comparison of means}

The next step after having demonstrated the equivalence of the SAGE's factors, loadings, and intercepts across early childhood and elementary school student teachers consisted in seeking differences and similarities in perceptions of GM implementation between one teacher education group and the other. As can be seen in Table 3, mean score comparisons by factors and items revealed statistically significant differences. Early childhood student teachers 
scored higher than elementary school ones in the assessment of the importance of including a gender perspective in university teaching $(M=5.37 v s .5 .00, t[396]=4.54, p<.01)$ and in awareness on gender inequalities $(M=2.56 v s .2 .37, t[396]=2.78, p<.01)$, the magnitude of differences in means being medium and small (Cohen's $d$ effect size of .457 and .261, respectively). No statistically significant differences between both groups appeared in perceptions of institutional sensitivity to the implementation of a GE policy ( $M=3.84 \mathrm{vs}$. $3.83, t[396]=0.12, p>.05)$. Taking into account that the midpoint of the scale is 3.50 , these data indicated that student teachers rated: (a) the incorporation of a gender perspective into training as very important and essential for their preparation; (b) the level of institutional sensitiveness to GE policy implementation in teaching as moderately low or neutral; and (c) the level of awareness of gender inequalities as very low or clearly inadequate.

Table 3 Student teachers' perceptions on gender mainstreamingimplementation by subsamples

\begin{tabular}{|c|c|c|c|c|c|c|c|c|c|}
\hline \multirow[b]{2}{*}{ Dimensions/Items } & \multicolumn{2}{|c|}{$\begin{array}{l}\text { Whole } \\
\text { Sample }\end{array}$} & \multicolumn{2}{|c|}{$\begin{array}{c}\text { Early } \\
\text { Childhood }\end{array}$} & \multicolumn{2}{|c|}{ Elementary } & \multirow[b]{2}{*}{$t$} & \multirow[b]{2}{*}{$g l$} & \multirow[b]{2}{*}{$p$} \\
\hline & $M$ & $S D$ & $M$ & $S D$ & $M$ & $S D$ & & & \\
\hline GE Training & 5.18 & 0.83 & 5.37 & 0.72 & 5.00 & 0.89 & 4.54 & 396 & $.000^{*}$ \\
\hline 19. Mainstreaming gender in TE is essential to combat sexism. & 5.22 & 0.95 & 5.41 & 0.85 & 5.04 & 1.01 & 3.88 & 396 & $.000^{*}$ \\
\hline 7. Mainstreaming gender should be mandatory and transversal. & 5.30 & 1.03 & 5.51 & 0.85 & 5.10 & 1.14 & 4.04 & 396 & $.000^{*}$ \\
\hline $\begin{array}{l}\text { 20. Gender issues are important for } \mathrm{TE} \text { as those related to other } \\
\text { differences. }\end{array}$ & 5.38 & 0.85 & 5.47 & 0.81 & 5.28 & 0.88 & 2.27 & 396 & $.024^{*}$ \\
\hline $\begin{array}{l}\text { 13. At least one course focused on gender studies in TE should be } \\
\text { compulsory. }\end{array}$ & 5.26 & 1.18 & 5.52 & 0.97 & 5.00 & 1.31 & 4.51 & 396 & $.000^{*}$ \\
\hline 12. All subjects should be taught with a gender perspective. & 4.84 & 1.27 & 5.11 & 1.13 & 4.58 & 1.35 & 4.28 & 396 & $.000^{*}$ \\
\hline $\begin{array}{l}\text { 11. Diversity of sexual identity should receive more attention in } \\
\text { study plans. }\end{array}$ & 4.93 & 1.09 & 5.13 & 0.97 & 4.74 & 1.17 & 3.68 & 396 & $.000^{\star}$ \\
\hline $\begin{array}{l}\text { 17. Mainstreaming gender in } \mathrm{TE} \text { is necessary for learning to teach } \\
\text { equality. }\end{array}$ & 5.34 & 0.99 & 5.42 & 0.93 & 5.26 & 1.04 & 1.63 & 396 & .105 \\
\hline Institutional Sensitiveness & 3.83 & 0.91 & 3.84 & 0.88 & 3.83 & 0.93 & .122 & 396 & .903 \\
\hline 15. My college of education has adopted a proactive approach to GE. & 3.92 & 1.14 & 3.95 & 1.15 & 3.89 & 1.13 & 0.55 & 396 & .582 \\
\hline 16. My college is implementing the current legislation related to GE. & 4.21 & 1.14 & 4.25 & 1.09 & 4.16 & 1.18 & 0.76 & 396 & .448 \\
\hline 3. Gender issues receive sufficient attention in course content. & 3.45 & 1.32 & 3.53 & 1.31 & 3.37 & 1.33 & 1.17 & 396 & .245 \\
\hline 14. Instructors are sufficiently sensitive to gender issues. & 3.72 & 1.20 & 3.65 & 1.16 & 3.79 & 1.23 & -1.14 & 396 & .266 \\
\hline 2. My study plan includes gender competence development. & 3.88 & 1.53 & 3.82 & 1.52 & 3.94 & 1.54 & -0.74 & 396 & .457 \\
\hline Awareness of Gender Inequalities & 2.44 & 0.89 & 2.56 & 0.87 & 2.37 & 0.89 & 2.78 & 396 & $.006^{*}$ \\
\hline 5. Female student achievement is frequently minimised. & 2.31 & 1.30 & 2.41 & 1.32 & 2.20 & 1.28 & 1.62 & 396 & .107 \\
\hline $\begin{array}{l}\text { 6. Achievements of female students are attributed to effort rather } \\
\text { than to ability. }\end{array}$ & 2.91 & 1.46 & 3.05 & 1.38 & 2.77 & 1.52 & 1.88 & 396 & .061 \\
\hline $\begin{array}{l}\text { 4. Male students receive more attention from faculty than their } \\
\text { female counterparts. }\end{array}$ & 1.87 & 1.20 & 2.03 & 1.32 & 1.71 & 1.04 & 2.62 & 396 & $.009^{*}$ \\
\hline 10. Faculty has higher expectations about male students. & 2.05 & 1.09 & 2.17 & 1.12 & 1.93 & 1.04 & 2.24 & 396 & $.026^{*}$ \\
\hline $\begin{array}{l}\text { 8. Female faculty find themselves in inferiority compared to male } \\
\text { faculty. }\end{array}$ & 2.80 & 1.44 & 2.92 & 1.36 & 2.69 & 1.52 & 1.59 & 396 & .112 \\
\hline 9. Power in university continues to be held by male faculty. & 2.71 & 1.38 & 2.82 & 1.40 & 2.61 & 1.36 & 1.46 & 396 & .145 \\
\hline
\end{tabular}

Scale range 1-6 ( 1 = I strongly disagree; 2 = I disagree to some extent; 3 = I disagree; $4=$ I agree to some extent; $5=$ I agree; $6=$ I strongly agree); *Significant at .05 or above 
The examination of results by items (Table 3 ) revealed that, apart from the statement "Mainstreaming gender in teacher education is necessary to learning to teach equality" (Item 17), where both groups strongly agreed ( $M=5.42$ and 5.26 , respectively), this was not the case in the rest of statements (items 19, 7, 20,13, 12 and 11). These findings suggest that early childhood student teachers were more receptive to the need of adopting a gendersensitive approach in teaching than elementary school student teachers. Early childhood student teachers also had a significantly greater awareness of gender inequalities compared to elementary school student teachers $(p<.01)$. Even though both groups were blind to gender inequalities associated with learning and teaching, elementary school student teachers perceived that male learners are likely to receive more attention from faculty than their female counterparts $(M=1.71 v s .2 .03, t[396]=2.62, p<.01)$ and also that faculty have higher expectations for male students $(M=1.93 v s .2 .17, t[396]=2.24, p<.05)$. These differences confirm the discriminatory capacity of items, alongside their potential to identify gaps in the process of gender mainstreaming implementation on an institutional, curricular, and individual basis, additionally justifying the use of the SAGE index as a screening and guidance instrument to introduce reforms and to assess impacts.

\section{DISCUSSION AND EDUCATIONAL IMPLICATIONS}

Several studies have shown that instrument validation may need modifications when used in new contexts after translation to other languages (e.g. Arafat et al., 2016) or with groups of different characteristics (e.g. Milfont \& Fischer, 2010). In regards to the SAGE index, previous research has not addressed measurement invariance when utilised with diverse teacher education programmes, with the exception of the study by Miralles-Cardona (2020), who studied invariance across sex and permitted to examine all the sources of measurement invariance due to population heterogeneity by sex. In this study, the original three-factor model of the SAGE index was tested for measurement invariance across two samples of early childhood and elementary student teachers being verified too using the best fit and most parsimonious model.

The first step in the study was to explore the descriptive statistics, internal consistency, and model fit estimates in the original three-factor model. Internal consistency estimates resembled those reported by Miralles-Cardona (2020) for male and female student teachers, which ranged from .67 to .77 . However, reliability estimates for the early childhood and elementary school student teacher samples ranged from .68 to .69. In other words, the SAGE index has slightly better internal consistency when studied across degree than across sex.

An important finding was that model fit estimates for the three-factor model of the 18item SAGE index across degree suggested an adequate model fit $\left(\chi^{2} / d f=3.50\right.$; RMSEA $<.08$; CFI > .90). However, Miralles-Cardona (2020) reported lower fit estimates across $\operatorname{sex}\left(\chi^{2} / d f=6.13\right.$; RMSEA $=.11$; CFI <.90) for the same sample using the 16 -item three factor of the SAGE, thus indicating an acceptable to mediocre fit. As hypothesised, the 18item SAGE index yielded invariant indicators: equivalent factors, equivalent loadings, and equivalent intercepts across the early childhood and elementary school student teacher sam- 
ples. Because multi-group model fit estimates for both samples were within the acceptable model fit range, the instrument can prove useful to compare perceptions on gender equality training, institutional sensitiveness to the implementation of a gender equality policy, and awareness of gender inequalities in teaching and learning.

When comparing student teachers' perceptions of GM incorporation into teaching, statistically significant differences in ratings of gender equality training were found between the two samples of student teachers $(p<.01)$, which in turn suggests that early childhood student teachers gave more importance to gender equality training as part of their preparation than elementary school student teachers in all indicators but one (Item 17). Early childhood student teachers also value GM more than their elementary school counterparts as a teaching strategy to combat sexism; they see GM as mandatory and consider that at least one subject focused on gender issues should be taught in teacher education plans. No statistically significant differences in ratings of institutional sensitivity on GM implementation were found between both samples $(p>.05)$, though, the level of commitment being rated as low (3.84 vs. 3.83 out of 6 ). This has important implications for teacher education at the participating institution because, as shown by data, participants believed that gender does not receive enough attention in course contents (Item 3 ), that instructors are not sufficiently sensitive to gender issues (Item 14), and that study plans do not sufficiently include gender competence development (Item 2). Finally, a very surprising result was that student teachers from both samples seem to be unaware of gender inequalities linked to instructional processes, with ratings of 2.56 and 2.37 out of 6 , elementary school student teachers being even less aware of these potential inequalities. These results suggest that gender education is absent from the teacher preparation curriculum. As for the three dimensions measured by the SAGE index, the areas of greatest concern are: (1) achieving the institution's commitment to implement and evaluate GM in teaching; and (2) sensitising students to possible unfair and discriminatory treatments.

Based on these findings, providing the participant institution with information on their students' perceptions of gender equality training can help to address the areas of concern related to GM implementation in university teacher education. In our view, the SAGE index has the potential to supply useful information to the School of Education and its faculty as well as to other researchers who may find this instrument helpful in their inquiry to provide evidence about the status of gender mainstreaming in teacher education from student teachers' perspectives.

\section{LIMITATIONS}

A limitation of this study had to do with using only two student teacher cohorts from a single higher education institution. Hence, a generalisation of our findings without additional validation research should be avoided. However, the instrument is reliable and valid for use in teacher education, and it can supply information about how future teachers view gender mainstreaming in their study plans and classroom activities. Bearing in mind that the participating institution in this study is positioned in the rank 101-200 (overall mean for 
GE 51.9 to 62.4 out of 100) in the Impact Ranking 2020: Gender Equality (World University Rankings, 2020), interventions to promptly improve gender institutional sensitiveness and student teachers awareness of gender inequities in learning and teaching become necessary. The ranking focuses on SDG\#5 and measures universities' research on the study of gender, along with their policies on gender equality and their commitment to recruiting and promoting women; and it includes more than 300 universities from 70 countries (World University Rankings, 2020). Overall, the results of this study issue a warning that teacher education for gender equality still remains a pending task at this institution. Being a valid and reliable tool, the SAGE index could serve to identify barriers to the implementation of GE policies, to guide reforms towards mainstreaming gender into faculties' ideologies and curricula, and to evaluate the impact after each intervention. Future studies with broader and more representative samples may contribute to better describe the status of gender mainstreaming in university teaching as well as to learn more about actions that need to be taken in common with other faculties of education and higher education institutions.

\section{CONCLUSION}

Taking into account that the main objective pursued with this study was to examine factor invariance in the SAGE index amongst early childhood and elementary school student teachers, it is concluded that:

1. The three-factor model of the 18-item SAGE index turns out to be acceptable in both samples of student teachers and invariant across degree, thus showing evidence of measurement cross-validation and stability in the two groups under study; and

2. Student teachers perceive gender equality training as 'much needed' and are aware that their institution is neutral and scarcely committed to the implementation of GM policy in its study plans. Nevertheless, they report unawareness of gender inequalities associated with educational processes too. Early childhood student teachers not only were significantly more receptive to the need for gender equality training but also showed a higher degree of awareness about gender inequalities than elementary school student teachers.

3. These findings reveal a clear demand for change and the participating institution should take note thereof.

\section{ACKNOWLEDGEMENTS}

This work was supported by the Alicante Institute of Culture Juan Gil-Albert (Ref. 4413) and by the 'Vice-Chancellor's Office for Educational Quality and Innovation of the University of Alicante (Ref. VIGROB-298).

Funded by: University of Alicante, Spain

Funder Identifier: http://dx.doi.org/10.13039/100009092

Award: VIGROB-298

Funded by: Alicante Institute of Culture Juan Gil-Albert, Spain. Award: 4413 


\section{REFERENCES}

Arafat, S. M., Chowdhury, H., Qusar, M. M. A., \& Hafez, M. A. (2016). Cross cultural adaptation and psychometric validation of research instruments: A methodological review. Journal of Behavioral Health, 5(3), 129-129. https://doi.org/10.5455/jbh.20160615121755

Arbuckle, J. L. (2014). AMOS 23 user's guide. Retrieved from ftp://public.dhe.ibm.com/software/ analytics/spss/documentation/amos/23.0/en/Manuals/IBM_SPSS_Amos_User_Guide.pdf

Browne, M. W., \& Cudeck, R. (1992). Alternative ways of assessing model fit. Sociological Methods \& Research, 21(2), 230-258. https://doi.org/10.1177/0049124192021002005

Cheung, G. W., \& Rensvold, R. B. (1999). Testing factorial invariance across groups: A reconceptualization and proposed new method. Journal of Management, 25(1), 1-27. https://doi.org/ $10.1177 / 014920639902500101$

Council of Europe. (2011). European Pact for Gender Equality 2011-2020. Retrieved from htps:// eur-lex.europa.eu/legal-content/EN/TXT/?uri=CELEX\%3A52011XG0525\%2801\%29

Council of Europe. (2018). Council of Europe gender equality strategy 2018-2023. Retrieved from https://rm.coe.int/strategy-en-2018-2023/16807b58eb

DeJaeghere, J. (2015). Reframing gender and education for the post-2015 Agenda: A critical capability approach. In S. McGrath \& Q. Gu (Eds.), Handbook of international education and development (pp. 63-77). Taylor and Francis.

European Institute for Gender Equality (EIGE). (2012-2013). Gender equality training in the European Union: Mapping, research and stakeholders' engagement. Retrieved from https://eige.europa.eu/news/gender-training-european-union-mapping-research-and -stakeholders-engagement-2012-2013

European Institute for Gender Equality (EIGE). (2014). Peer-to-peer exchange seminar: How do we make gender mainstreaming work? Retrieved from https://oqconsulting.eu/wp-content/ uploads/2019/07/Final_Report_Peer_to_Peer_Seminar_Nov_20.pdf

European Institute for Gender Equality (EIGE). (2016). Gender equality training: Gender mainstreaming toolkit. Retrieved from https://eige.europa.eu/publications/gender-equality -training-gender-mainstreaming-toolkit

European Parliament. (2003). Summary of the Treaty of Nice. Retrieved from https://ec.europa.eu/ commission/presscorner/detail/en/MEMO_03_23

European Parliament. (2009). The Treaty of Lisbon. Retrieved from http://www.europarl.europa.eu/ $\mathrm{ftu} / \mathrm{pdf} / \mathrm{en} / \mathrm{FTU}$ 1.1.5.pdf

Fontaine, J. R. J. (2005). Equivalence. In K. Kempf-Leonard (Ed.), Encyclopedia of social measurement (pp. 803-813). Academic Press.

García-Ramos, F. J., Zurian-Hernández, F. A., \& Núñez-Gómez, P. (2020). Los estudios de género en los grados de comunicación. Comunicar, 63, 21-30. https://doi.org/10.3916/C63-2020-02

González-Pérez, T. (2017). Políticas educativas igualitarias en España: la igualdad de género en los estudios de magisterio. Archivos Analíticos de Políticas Educativas, 26(2), 1-17. https:// doi.org/10.14507/epaa.26.2764

Guarinos, V., Caro, F. J., \& Cobo-Durán, S. (2018). La igualdad de género en los estudios de grado en Comunicación: la transversalidad imaginaria. Revista Prisma Social, 22, 296-325. Retrieved from https://revistaprismasocial.es/article/view/2571

Hu, L., \& Bentler, P. M. (1999). Cutoff criteria for fit indexes in covariance structure analysis: Conventional criteria versus new alternatives. Structural Equation Modeling: A Multidisciplinary Journal, 6(1), 1-55. https://doi.org/10.1080/10705519909540118

Kabeer, N. (2005). Gender equality and women's empowerment: A critical analysis of the third millennium development goal 1. Gender \& Development, 13(1), 13-24. https://doi.org/10 
$.1080 / 13552070512331332273$

Kitta, I., \& Cardona-Moltó, M. C. (2020). Adaptación y validación de la versión griega del índice EFIG (Evaluación de la Formación para la Igualdad de Género) en estudiantes universitarios. In R. Roig Vila (Ed.), Nuevas aportaciones desde la investigación e innovación educativas (pp. 259-268). Octaedro.

Larrondo, A., \& Rivero, D. (2019). A case study on the incorporation of gender-awareness into the university journalism curriculum in Spain. Gender and Education, 31(1), 1-14. https:// doi.org/10.1080/09540253.2016.1270420

Lombardo, E., \& Mergaert, L. (2013). Gender mainstreaming and resistance to gender training: A framework for studying implementation. NORA - Nordic Journal of Feminist and Gender Research, 21(4), 296-311. http://doi.org/10.1080/08038740.2013.851115

Milfont, T. L., \& Fischer, R. (2010). Testing measurement invariance across groups: applications in cross-cultural research. International Journal of Psychological Research, 3(1), 111-130. https:// doi.org/10.21500/20112084.857

Miralles-Cardona, C. (2019). Evidencias de fiabilidad y validez del índice de Evaluación Sensible a la Formación en Igualdad de Género [Reliability and validity evidence of the Sensitive Assessment for Gender Equality index]. In R. Roig-Vila (Ed.), Investigación e innovación en la enseñanza superior: nuevos contextos, nuevas ideas (pp. 320-331). Octaedro.

Miralles-Cardona, C. (2020). Examining preservice teachers' education for gender equality using a gender sensitive scale: A case from Spain. In E. J. Byker \& A. Horton (Eds.), Elementary education: Global perspective, challenges and issues of the 21st century (pp. 99-126). Nova Science Publishers.

Miralles-Cardona, C., Cardona-Moltó, M. C., \& Chiner, C. (2020). La perspectiva de género en la formación inicial de docentes: estudio descriptivo de las percepciones del alumnado [Student perceptions of gender mainstreaming in initial teacher education: A descriptive study]. Educación XX1, 23(2), 231-257. https://doi.org/10.5944/educXX1.23899

Muthén, B., \& Kaplan, D. (1985). A comparison of some methodologies for the factor analysis of non-normal Likert variables. British Journal of Mathematical and Statistical Psychology, 38(2), 171-189. https://oi.org/10.1111/j.2044-8317.1985.tb00832.x

Ortega-Sánchez, D., \& Pagès-Blanch, J. (2018). Género y formación del profesorado: análisis de las guías docentes del área de Didáctica de las Ciencias Sociales. Contextos Educativos. Revista de Educación, 21(21), 53-53. https://doi.org/10.18172/con.3315

Pastor, I., \& Acosta, A. (2016). La institucionalización de las políticas de igualdad de género en la universidad española. Avances y retos. Investigaciones Feministas, 7, 247-271. https://doi.org/ 10.5209/INFE.52966

Pendergast, D., Garvis, S., \& Keogh, J. (2011). Pre-service student-teacher self-efficacy beliefs: An insight into the making of teachers. Australian Journal of Teacher Education, 36(12), 46-57. https://doi.org/10.14221/ajte.2011v36n12.6

Rands, K. E. (2009). Considering Transgender People in Education. Journal of Teacher Education, 60(4), 419-431. https://doi.org/10.1177/0022487109341475

Serra, P., Soler, S., Prat, M., Vizcarra, M. T., Garay, B., \& Flintoff, A. (2018). The (in)visibility of gender knowledge in the Physical Activity and Sport Science degree in Spain. Sport, Education and Society, 23(4), 324-338. https://doi.org/10.1080/13573322.2016.1199016

Spanish Government. (2004, December 29). Ley Orgánica 1/2004, de 28 de diciembre, de Medidas de Protección Integral contra la Violencia de Género [Organic Law 1/2004, of December 28, on Comprehensive Protection Measure against Gender Violence]. State Official Gazette/Boletin Oficial del Estado, 133, 1-44.

Spanish Government. (2007, March 23). Ley Orgánica 3/2007, de 22 de marzo, para la Igualdad 
Efectiva de Hombres y Mujeres [Organic Law 1/2004, of December 28, for the Effective Equality of Men and Women]. State Official Gazette/Boletin Oficial del Estado, 71, 1-66.

Thorndike, R. M. (1997). Measurement evaluation in psychology and education. Prentice-Hall.

UN Women Training Centre. (2015). Training for gender equality: Twenty years on. Retrieved from https://www.slideshare.net/LucyFerguson3/papertrainingforgenderequality20b-62417254

UNESCO. (2015). A guide for gender equality in teacher education: Policy and practices. Retrieved from ttp://unesdoc.unesco.org/images/0023/002316/231646e.pdf

United Nations. (1979). Convention on the Elimination of All Forms of Discrimination against Women $(C E D A W)$. Retrieved from https://www.ohchr.org/EN/ProfessionalInterest/Pages/CEDAW .aspx

United Nations. (1995). Beijing Platform for Action. Retrieved from https://www.un.org/en/events/ pastevents/pdfs/Beijing_Declaration_and_Platform_for_Action.pdf

United Nations. (2015). Transforming our world: The 2030 Agenda for Sustainable Development. Retrieved from https://sustainabledevelopment.un.org/post2015/transformingourworld

University of Alicante. (2018). The UA in figures 2017. Retrieved from https://utc.ua.es/es/ documentos/ua-en-cifras/libros-ua-en-cifras/libro-ua-en-cifras-2017-para-imprimir.pdf

Unterhalter, E., Heslop, J., \& Mamedu, A. (2013). Girls claiming education rights: Reflections on distribution, empowerment and gender justice in Northern Tanzania and Northern Nigeria. International Journal of Educational Development, 33(6), 566-575. https://doi.org/10.1016/ j.ijedudev.2013.05.007

Valdivieso, S., Ayuste, A., Rodríguez-Menéndez, M. C., \& Vila-Merino, E. (2016). Educación y género en la formación docente en un enfoque de equidad y democracia. In C. I. and Flores et al. (Eds.), Democracia y educación en la formación docente (pp. 117-140). Universidad de Vic-Universidad Central de Cataluña.

Vandenberg, R. J., \& Lance, C. E. (2000). A review and synthesis of the measurement invariance literature: Suggestions, practices, and recommendations for organizational research. Organizational Research Methods, 3(1), 4-70. https://doi.org/10.1177/109442810031002

Verge, T., Ferrer-Fons, M., \& González, M. J. (2018). Resistance to mainstreaming gender into the higher education curriculum. European Journal of Women's Studies, 25(1), 86-101. https:// doi.org/10.1177/1350506816688237

Vizcarra, M. T., Nuño, T., Lasarte, G., Aristizabal, M. P., \& Uria, A. A. (2015). La perspectiva de género en los títulos de Grado en la Escuela Universitaria de Magisterio de VitoriaGasteiz. REDU. Revista de Docencia Universitaria, 13, 297-297. https://doi.org/10.4995/ redu. 2015.6448

Weiner, G. (2000). A critical review of gender and teacher education in Europe. Pedagogy, Culture, and Society, 8(2), 233-247. https://doi.org/10.1080/14681360000200091

West, C., \& Zimmerman, D. H. (1987). Doing Gender. Gender \& Society, 1(2), 125-151. https:// doi.org/10.1177/0891243287001002002

WHO (World Health Organization). (2000). Millennium development goals. Retrieved from https:// www.who.int/topics/millennium_development_goals/about/en/

World University Rankings. (2020). Impact rankings 2020: gender equality. Retrieved from https://www.timeshighereducation.com/rankings/impact/2020/gender-equality\#!/page/0/ length/25/sort_by/rank/sort_order/asc/cols/undefined 